\title{
Occurrence of Listeria monocytogenes and Salmonella Typhimurium in Fruit Juices from Local Stalls and Restaurant in Kuching, Sarawak
}

\author{
CHAI SIAW YEW, CHAI SZE FAN, ROSDI KIRA, AHMAD SYATIR TAHAR and LESLEY \\ MAURICE BILUNG*
}

\author{
Faculty of Resource Science and Technology, Universiti Malaysia Sarawak, 94300 Kota Samarahan, Sarawak, \\ Malaysia \\ *Corresponding author: mblesley@unimas.my
}

\begin{abstract}
Listeria spp. and Salmonella spp. are capable of causing food-borne outbreaks and diseases in humans. This study aimed to quantify and detect the occurrence of Listeria monocytogenes and Salmonella Typhimurium in fruit juices by utilizing Most Probable Number (MPN) in combination with Polymerase Chain Reaction (PCR). In this study, a total of 50 fruit juice samples, consisting of orange, papaya, watermelon, honeydew and apple were collected from Kota Samarahan and Kuching. Specific Polymerase Chain Reaction (PCR) assay targeting the virulence gene, hlyA gene in L. monocytogenes and fliC gene in $S$. Typhimurium was performed, with the expected size of $730 \mathrm{bp}$ and $559 \mathrm{bp}$, respectively. MPN analysis showed that the estimated microbial loads of Listeria spp. and Salmonella spp. in all samples were more than $1100 \mathrm{MPN} / \mathrm{g}$. However, based on the PCR analysis, none of the samples $(0 \%)$ were positive for L. monocytogenes or S. Typhimurium. This study presented as a preliminary food safety screening for the occurrence of Listeria spp. and Salmonella spp. from retailed fruit juices. Hygienic practices and food safety measures should be adhered by all food vendors and restaurants in order to avoid foodborne disease outbreaks in the future.
\end{abstract}

Keywords: fliC, hlyA, Listeria, PCR, Salmonella

Copyright: This is an open access article distributed under the terms of the CC-BY-NC-SA (Creative Commons Attribution-NonCommercialShareAlike 4.0 International License) which permits unrestricted use, distribution, and reproduction in any medium, for non-commercial purposes, provided the original work of the author(s) is properly cited.

\section{INTRODUCTION}

Fruits are rich in vitamins, minerals and fibers which are essential component in a healthy diet. They are becoming a popular choice of dietary supplement in the modern days society as healthy eating is part of a dietary routine. Despite their health benefits, fruits are also capable of harboring pathogenic microorganisms. As fresh fruits are minimally-processed with no proper disinfection techniques, the probability of acquiring food-borne infections are high. The disease threat is exacerbated when the fruits are eaten raw (Nillian et al., 2011). Normally, fresh fruit juices are prepared by extraction or mechanical means, and have no or little steps taken to reduce contamination and pathogen level (Victorian Government Department of Human Services, 2005). Contamination sourced from raw fruits, equipment and food handlers involved in fruit juices preparation can transmit bacteria to the final products. With the rise in these ready-to-eat foods, attention has been drawn towards the foodborne disease associated with fresh fruits such as salmonellosis and listeriosis.

Listeria monocytogenes (L. monocytogenes) is a Gram-positive, facultatively anaerobic, non-spore forming, rodshaped bacteria that is known to be the causative agent of listeriosis (Jeyaletchumi et al., 2010). Listeriosis can cause abortions and premature deliveries, septicemia and meningitis among neonates. In immunocompromised individuals, it can cause meningitis, encephalitis, meningoencephalitis (Jadhav, Bhave \& Palombo, 2012). A study that was conducted in Malaysia by Jeyaletchumi et al. (2010) found that L. monocytogenes was present in the fresh juice samples. HlyA gene is a virulent gene which encodes for Listeriolysin O (LLO) toxin, that is responsible to promote haemolytic activity. It can be used to detect the presence of L. monocytogenes. In Malaysia, $L$. monocytogenes has been detected in various food samples including raw and ready-to-eat foods such as vegetarian burger patties, salad, vegetables, chicken and egg products (Jamali, Chai \& Thong, 2012; Marian et al., 2012; Wong et al., 2011).

Salmonellosis is a foodborne disease caused by the Salmonella bacteria. Among Salmonella serovars, $S$. Typhimurium and $S$. Enteritidis are the most common causes of salmonellosis. The genus Salmonella is within the family Enterobacteriaceae, that is morphologically and biochemically homogenous group of facultatively anaerobic, non-spore forming, Gram-negative rod-shaped bacteria. A local study by Diana, Pui and Son (2012) reported that the highest prevalence of Salmonella spp. was in carrot juice while S. Typhimurium was the highest 
in apple juice. The study concluded that the level of ascorbic acid in the fruit juices was the main factor that affected the $\mathrm{pH}$ needed for growth of the Salmonella.

However, there is a scarcity of information on the distribution of L. monocytogenes and S. Typhimurium in fruit juices retailed in East Malaysia (Sarawak). Therefore, the present study aimed to enumerate and detect $L$. monocytogenes and $S$. Typhimurium in fruit juices retailed in Kota Samarahan and Kuching by MPN method and PCR analysis.

\section{MATERIALS \& METHODS}

\section{Sample collection and processing}

Fifty fresh fruit juices were purchased from fruit juice stalls and restaurants located in Kota Samarahan and Kuching, Sarawak. The fruit types and the number of samples are shown in Table 1 and 2 . The fruit juice samples were placed in an ice box immediately after collection and they were processed at the Molecular Microbiology Laboratory, Faculty Resource Science and Technology, Universiti Malaysia Sarawak (UNIMAS).

Table 1. Fruit types and the number of fruit juices examined for the detection and concentration of Listeria spp. and L. monocytogenes.

\begin{tabular}{ccc}
\hline Types of Fruit & Scientific name & Number of samples \\
\hline Orange & Citrus sinensis & 10 \\
Papaya & Carica papaya & 10 \\
Watermelon & Citrullus lanatus & 10 \\
Honeydew & Cucumis melo & 10 \\
Apple & Malus domestica & 10 \\
\hline Total: & & 50 \\
\hline
\end{tabular}

Table 2. Fruit types and the number of fruit juices examined for the detection and concentration of Salmonella spp. and $S$. Typhimurium.

\begin{tabular}{ccc}
\hline Types of Fruit & Scientific name & Number of samples \\
\hline Orange & Citrus sinensis & 10 \\
Guava & Psidium & 10 \\
Watermelon & Citrullus lanatus & 10 \\
Honeydew & Cucumis melo & 10 \\
Apple & Malus domestica & 10 \\
\hline Total: & & 50 \\
\hline
\end{tabular}

\section{Pre-enrichment for Listeria spp. and Salmonella spp.}

Sample processing for Listeria spp. and Salmonella spp. was performed as described by Wong et al. (2011) and Malorny and Helmuth (2003), respectively. Listeria spp. were enriched by transferring $10 \mathrm{ml}$ of the samples into $90 \mathrm{ml}$ of Tryptic Soy Broth (Becton, Dickinson \& Company, France). While, Salmonella spp. were enriched by transferring $10 \mathrm{ml}$ of the samples into $90 \mathrm{ml}$ of Buffered Peptone Water (Merck, Germany). Afterwards, the broths were incubated at $37^{\circ} \mathrm{C}$ for $24 \mathrm{hr}$.

\section{Enumeration by Most Probable Number (MPN) Method}

The pre-enriched samples were subjected to the three-tube MPN analysis as described in Sutton (2010). The samples were diluted with three-fold dilution series. Briefly, the homogenised fluid from each of the enriched fruit juice samples was serially diluted into 100 -fold and 1000-fold dilutions with nutrient broth (Merck, Germany) and incubated at $37^{\circ} \mathrm{C}$ for 24 hours. After incubation, the turbid tubes were chosen for DNA extraction.

\section{DNA Extraction}

Boil cell method as described by Diana et al. (2011) was adapted in this study. Briefly, $1 \mathrm{ml}$ of the enriched bacterial cultures in the broth was centrifuged (Hettich EBA 21 Zentrifugen, Germany) at 12,000 rpm for $3 \mathrm{~min}$. The supernatant was discarded, and the cell pellet was re-suspended in $200 \mu 1$ of sterile distilled water and was vortexed (Labnet International, USA). The cell suspension was boiled for $15 \mathrm{~min}$ and immediately cooled at -20 ${ }^{\circ} \mathrm{C}$ for 15 min before being centrifuged again (Hettich EBA 21 Zentrifugen, Germany) for 3 min at 12,000 rpm. 


\section{PCR Assay for the Detection of Listeria monocytogenes}

PCR assay was performed as described by Kargar and Ghasemi (2009) with minor modifications in the concentration of reagents and primer used. One set of primers as summarized in Table 3 was used to detect hlyA gene in L. monocytogenes isolates.

Table 3. Primers used for the detection of Listeria monocytogenes.

\begin{tabular}{clcc}
$\begin{array}{c}\text { Targeted } \\
\text { gene }\end{array}$ & Primer nucleotide sequences (5' $\left.-3^{\prime}\right)$ & $\begin{array}{c}\text { Amplicon } \\
\text { Size }(\mathrm{bp})\end{array}$ & Reference \\
\hline$h l y A$ & $h l y$ A-F CAT TAG TGG AAA GAT GGA ATG & 730 & (Gouws \& Liedemann, \\
& $h l y$ A-R GTA TCC TCC AGA GTG ATC GA & & \\
\hline
\end{tabular}

Prior to the PCR assay, positive and negative controls were prepared. The positive control contained $5 \mu$ l of DNA template of L. monocytogenes ATCC 15313 (American Type Culture Collection, USA), whereas $5 \mu$ l of sterile distilled water was used as the negative control. The amplification was performed in the Eppendorf Mastercycler ${ }^{\circledR}$ Personal (Hamburg, Germany). An initial denaturation was started at $95{ }^{\circ} \mathrm{C}$ for $5 \mathrm{~min}$, followed by 35 cycles each of denaturation at $95{ }^{\circ} \mathrm{C}$ for $1 \mathrm{~min}$, primer annealing at $62{ }^{\circ} \mathrm{C}$ for $45 \mathrm{sec}$ and extension at $72{ }^{\circ} \mathrm{C}$ for $1 \mathrm{~min}$, and a final extension at $72{ }^{\circ} \mathrm{C}$ for $5 \mathrm{~min}$. The presence of amplified hlyA gene fragment was detected by using gel electrophoresis with $1.2 \%$ of agarose gel, $0.5 \mathrm{X}$ TBE buffer at $80 \mathrm{~V}$ for $1 \mathrm{~h}$ before visualization under UV transilluminator.

\section{PCR Assay for the Detection of Salmonella Typhimurium}

PCR was carried out as described by Jamshidi, Bassami and Afshari-Nic (2009) and Soumet et al. (1999). Fli15F and Tym-R primers were used specific for Salmonella Typhimurium with fliC gene (Table 4). The PCR reactions were carried out with $25 \mu 1$ amplification mixture.

Table 4. Primers used for the detection of Salmonella Typhimurium.

\begin{tabular}{ccccc}
\hline $\begin{array}{c}\text { Target } \\
\text { Gene }\end{array}$ & Primer sets & Nucleotide sequences (5' to 3') & $\begin{array}{c}\text { Amplicon } \\
\text { size (bp) }\end{array}$ & Reference \\
\hline $\begin{array}{l}\text { fliC } \\
\text { gene }\end{array}$ & Fli15-F & CGG TGT TGC CCA GGT TGG TAA T & 559 & $\begin{array}{c}\text { Jamshidi } \text { et } \\
\text { al. (2009) }\end{array}$ \\
& Tym-R & ACT CTT GCT GGC GGT GCG ACT T & & \\
\hline
\end{tabular}

Positive and negative controls were included in each PCR assay. The positive control contained $5 \mu$ of DNA template of $S$. Typhimurium ATCC 14028 (American Type Culture Collection, USA), whereas $5 \mu$ l of sterile distilled water was used as the negative control. The amplification was performed in the Eppendorf Mastercycler ${ }^{\circledR}$ Personal (Hamburg, Germany). An initial denaturation was started at $95{ }^{\circ} \mathrm{C}$ for $5 \mathrm{~min}$, followed by 35 cycles each of denaturation at $94{ }^{\circ} \mathrm{C}$ for $1 \mathrm{~min}$, primer annealing at $56{ }^{\circ} \mathrm{C}$ for $30 \mathrm{sec}$ and extension at $72{ }^{\circ} \mathrm{C}$ for $30 \mathrm{sec}$ and a final extension at $72{ }^{\circ} \mathrm{C}$ for $10 \mathrm{~min}$. The presence of amplified fliC gene fragment was detected by using gel electrophoresis with $1.2 \%$ of agarose gel, $0.5 \mathrm{X}$ TBE buffer at $85 \mathrm{~V}$ for one hour before visualization under UV transilluminator.

\section{RESULTS \& DISCUSSIONS}

The findings from pre-enrichments indicated that all the fruit juices $(n=100)$ showed turbidity in the Tryptic Soy Broth and Buffered Peptone Water. Furthermore, the MPN analysis revealed that all samples were contaminated with more than $1100 \mathrm{MPN} / \mathrm{g}$ of Listeria spp. and Salmonella spp. Tables 5 and 6 summarize the results for the detection of Listeria spp. and L. monocytogenes, and Salmonella spp. and S. Typhimurium, respectively in five different fruit juices collected from local stalls and restaurants.

The agarose gel images for the detection of hlyA (L. monocytogenes) and fliC (S. Typhimurium) genes in fruit juices are shown in Figures 1 and 2, respectively. Nevertheless, no visible bands were detected at 730 bp (for hlyA gene) and $559 \mathrm{bp}$ (for fliC gene), respectively. 
Table 5. Detection of Listeria spp. and L. monocytogenes in five different fruit juices collected from local stalls and restaurants.

\begin{tabular}{ccc}
\hline $\begin{array}{c}\text { Types of } \\
\text { Fruit Juice } \\
\text { (Total isolates) }\end{array}$ & $\begin{array}{c}\text { Preliminary detection of Listeria } \\
\text { spp. by MPN/g } \\
\text { (No. positive Isolates) }\end{array}$ & $\begin{array}{c}\text { PCR Detection of Listeria } \\
\text { monocytogenes }\end{array}$ \\
\hline $\begin{array}{c}\text { Apple } \\
(n=10)\end{array}$ & (Percentage of positive Isolates) \\
$\begin{array}{c}\text { Orange } \\
(n=10) \\
\text { Watermelon } \\
(n=10) \\
\text { Honeydew } \\
(n=10) \\
\text { Papaya } \\
(n=10)\end{array}$ & $>1100(n=50)$ & $0 / 50(0 \%)$ \\
& & \\
\hline
\end{tabular}

Table 6. Detection of Salmonella spp. and S. Typhimurium in five different fruit juices collected from local stalls and restaurants.

\begin{tabular}{ccc}
\hline $\begin{array}{c}\text { Types of Fruit Juice } \\
\text { (Total isolates) }\end{array}$ & $\begin{array}{c}\text { Preliminary Detection of Salmonella } \\
\text { spp. MPN/g } \\
\text { (No. positive Isolates) }\end{array}$ & $\begin{array}{c}\text { PCR Detection of Salmonella } \\
\text { Typhimurium } \\
\text { (Percentage of positive Isolates) }\end{array}$ \\
\hline $\begin{array}{c}\text { Apple } \\
(n=10)\end{array}$ & $>1100(n=50)$ & $0 / 50(0 \%)$ \\
$\begin{array}{c}\text { Orange } \\
(n=10) \\
\text { Watermelon } \\
(n=10) \\
\text { Honeydew } \\
(n=10) \\
\text { Guava } \\
(n=10)\end{array}$ & \\
\hline
\end{tabular}

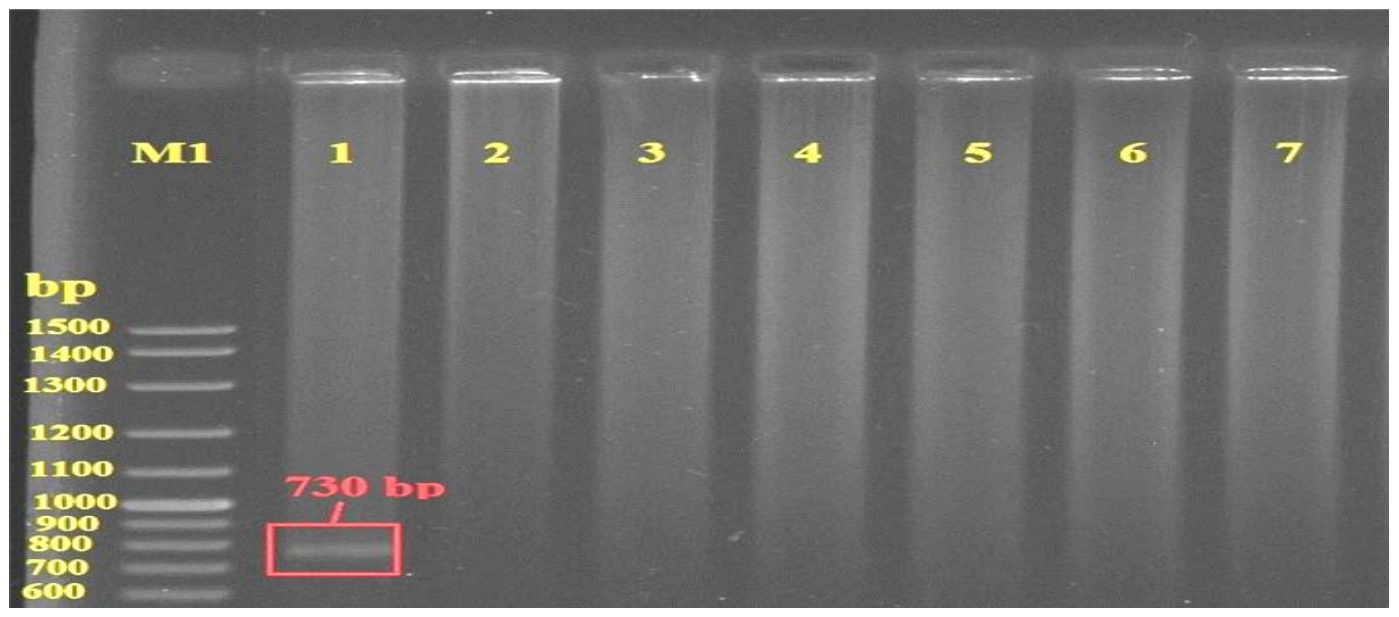

Figure 1. Representative gel image of PCR amplification of $h l y A$ gene detection from five different fruit juice samples. M1: 100-bp DNA ladder; Lane 1: L. monocytogenes positive control (ATCC 15313), lane 2: negative control, lane 3 - 7: apple, orange, watermelon, honeydew and papaya juice samples. 


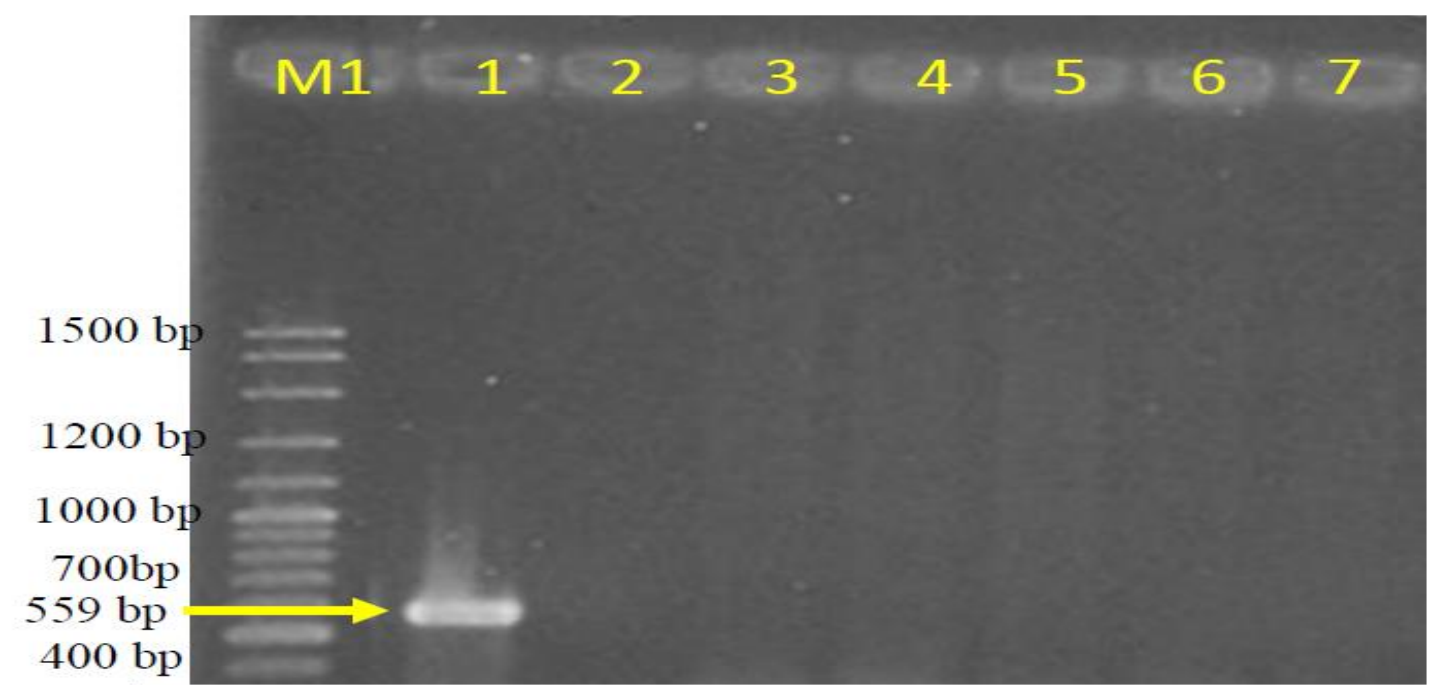

Figure 2. Representative gel image of PCR amplification of fliC gene detection from five different fruit juice samples. M1: 100-bp DNA ladder; Lane 1: Positive control for $S$. Typhimurium; Lane 2: Negative control; Lane 3-7: apple, orange, watermelon, honeydew and guava juice samples.

In this study, no sample of fruit juices $(n=0 / 50)$ was positive with $L$. monocytogenes and $S$. Typhimurium from the PCR analysis. The absence of Listeria spp. and Salmonella spp. in this study is due to the vertical growing mechanism of the fruit from the soil which indirectly reduce the potential of Listeria or Salmonella contamination. (Brackett, 2007). It has been frequently reported that Salmonella was detected from other foods such as meat, vegetables and seafood. A study by Titarmare, Dabholkar and Godbole (2009) reported that almost 50\% of vegetable juice samples tested in the study, showed the presence of Salmonella.

Contamination of fruit juices can result from cross-contamination or mishandling during harvesting, processing, transporting and during juices preparation (Diana et al., 2012). Pathogen reduction depends largely on the hygienic and sanitary production and processing practices used to reduce colonization, transmission and crosscontamination among foods and environment (Huda \& Adzitey, 2010). In this study, the fruit juice samples were mostly collected from fruit juice stalls at malls and restaurants. It was noteworthy that the environments of fruit juice stalls and restaurants were tidier, cleaner and had more favourable hygienic status compared to hawker stalls. This includes proper sanitary practices presented by the stall workers (malls and restaurants) such as wearing gloves, proper hand washing practices, and washing fruits and utensils at every preparation. The fruits were washed to remove any visible debris and dirt on the fruits. According to Park, Alexander, Taylor, Costa and Kang (2008), chlorinated or electrolyzed water can be used to decontaminate foodborne pathogen on fruits. In this recent study, pasteurized milk was added to the papaya juice during the preparation. Addition of pasteurized milk to fruit juices can be a source of Listeria contamination particularly L. monocytogenes that is commonly associated with tainted milk products. However, PCR detection assay revealed the absence of L. monocytogenes in the papaya juice samples and it is suggested that the milk added was well pasteurized. This is supported by Lado and Yousef (2007), which highlighted that high temperature during pasteurization process can eliminate bacteria.

As opposed to the similar study conducted by Diana et al. (2012) in West Malaysia, this study in East Malaysia showed no presence of $S$. Typhimurium in fruit juices. The utilization of purified and distilled water during the preparation of fruit juices is a contributing factor to the absence of $S$. Typhimurium in the fruit juice samples. Purified water normally contains fewer microorganisms than non-purified water. Fresh-cut fruits were further subjected to storage in refrigerator. Chilling process $\left(<4{ }^{\circ} \mathrm{C}\right)$ helps to inhibit the growth of Salmonella. Through our observation, the hawkers used purified water from a purified filter system and reverse osmosis drinking water in the making of fruit juice. This further minimizes the contamination of Salmonella as the water had been treated.

The nature of apple, orange and guava growing on trees minimise the chances for the fruits to harbour contaminants from soil. A study by Ukuku and Sapers (2006) stated that the smooth surface of honeydew and watermelon provides less microbial attachment sites and thus the microorganisms can be easily washed off during washing treatment. Besides, adequate amount of sugar in food and drinks can absorb water content which leads to the deterioration of bacterial growth (Trickett, 2001). 


\section{CONCLUSION}

This study highlighted the absence of L. monocytogenes and $S$. Typhimurium in the fruit juices samples tested. Overall, this study serves as a preliminary study on the current safety level of fruit juices consumption (towards Listeria spp. and Salmonella spp.) purchased from local fruit stalls and restaurants. The absence of $L$. monocytogenes and $S$. Typhimurium in this study may be due to hygienic and sanitary production and processing practises at the sampling premises assist in reducing the possibilities of foodborne bacterial contamination. Proper temperature and shorter storage period of fruits are also encouraged to further reduce microbial contamination on ready to eat fruits.

\section{ACKNOWLEDGEMENTS}

This work was supported by the internal funds in UNIMAS.

\section{REFERENCES}

Brackett, R. E. (2007). Incidence and behaviour of Listeria monocytogenes in product of plant origin. In T. R. Elliot \& H. M. Elmer (Eds.), Listeria, listeriosis and food safety ( $3^{\text {rd }}$ ed.) (pp. 655-676). United States: CRC Press.

Diana, J. E., Pui, C. F., \& Son, R. (2012). Enumeration of Samonella spp., Salmonella Typhi and Samonella Typhimurium in fruit juices. International Food Research Journal, 19(1), 51-56.

Gouws, P. A., \& Liedemann, I. (2005). Evaluation of diagnostic PCR for the detection of Listeria monocytogenes in food products. Food Technology Biotechnology, 43(2), 201-205.

Huda, N., \& Adzitey, F. (2010). Listeria monocytogenes in foods: incidences and possible control measures. African Journal of Microbiology Research, 4(25), 2848-2855.

Jadhav, S., Bhave, M., \& Palombo, E. A. (2012). Methods used for the detection and subtyping of Listeria monocytogenes. Journal of Microbiological Methods, 88(3), 327-341.

Jamali, H., Chai, L. C., \& Thong, K. L. (2012). Detection and isolation of Listeria spp. and Listeria monocytogenes in ready-to-eat foods with various culture media. Food Control, 32, 19-24.

Jamshidi, A., Bassami, M. R., \& Afshari-Nic, S. (2009). Identification of Salmonella spp. and Salmonella Typhimurium by a multiplex PCR-based assay from poultry carcasses in Mashhad-Iran. Iranian Journal of Veterinary Medicine, 3(1), 43-48.

Jeyaletchumi, P., Tunung, R., Margaret, S. P., Son, R., Ghazali, F. M., Cheah, Y. K., Nishibuchi, M., Nakaguchi, Y., \& Malakar, P. K. (2010). Quantification of Listeria monocytogenes in salad vegetables by MPN-PCR. International Food Research Journal, 17, 281-286.

Kargar, M., \& Ghasemi, A. (2009). Roles of Listeria monocytogenes hlyA gene isolated from fresh cheese in human habitual abortion in Marvdasht. Iranian Journal of Clinical Infectious Diseases, 4(4): 214-218.

Lado, B. H., \& Yousef, A. E. (2007). Characteristics of Listeria monocytogenes important to food processors. In T. R. Elliot \& H. M. Elmer (Eds.), Listeria, listeriosis and food safety (3 ${ }^{\text {rd }}$ ed.) (pp. 158-198). United States: CRC Press.

Malorny, B., \& Helmuth, R. (2003). Detection of Salmonella spp. In K. Sachse \& J. Frey (Eds.), PCR detection of microbial pathogens (pp. 275-287). Totowa, NJ: Humana Press Inc.

Marian, M. N., Sharifah, S. M., Zuraini, M. I., Son, R., Maimunah, M., Lee, H. Y., Wong, W. C., \& Elexson, N. (2012). MPN-PCR detection and antimicrobial resistance of Listeria monocytogenes isolated from raw and ready-to-eat foods in Malaysia. Food Control, 28(2), 309-314.

Nillian, E., Chai, L. C., Pui, C. F., Robin, T., Anyi, U., Tuan Chilek, T. Z., Radu, S., \& Nishibuchi, M. (2011). Simultaneous detection of Salmonella spp., Salmonella Enteritidis and Salmonella Typhimurium in raw salad vegetables and vegetarian burger patties. Food and Nutrition Sciences, 2, 1077-1081.

Park, E. J., Alexander, E., Taylor, G. A., Costa, R., \& Kang, D. H. (2008). Effect of electrolyzed water for reduction of foodborne pathogen on lettuce and spinach. Food Microbiology and Safety, 73(6), 268-272.

Soumet, C., Ermel, G., Rose, V., Drouin, P., Salvat, G., \& Colin, P. (1999). Identification by a multiplex PCRbased assay of Salmonella Typhimurium and Salmonella Enteritidis strains from environmental swabs of poultry houses. Letters in Applied Microbiology, 29, 1-6.

Sutton, S. (2010). The most probable number method and its uses in enumeration, qualification, and validation. Journal of Validation Technology, 16(3), 35-38.

Titarmare, A., Dabholkar, P., \& Godbole, S. (2009). Bacteriological analysis of street vended fresh fruit and vegetable juices in Nagpur city, India. Internet Journal of Food Safety, 11, 1-3.

Trickett, J. (2001). The prevention of food poisoning. London: Nelson Thornes Ltd.

Ukuku, D. O., \& Sapers, G. M. (2006). Effect of time before storage and storage temperature on survival of Salmonella inoculated on fresh-cut melons. Food Microbiology, 24, 288-295. 
Victorian Government Department of Human Services. (2005). Microbiological survey of freshly squeezed juices from retail businesses across Vicoria. Retrieved March 2, 2013, from http://www.health.vic.gov.au/archive/archive2011/foodsafety/archive/downloads/fruit juice_survey report aug05.pdf.

Wong, W. C., Pui, C. F., Chai, L. C., Lee, H. Y., Ghazali, F. M., Tang, J. Y. H., Ponniah, J., Tuan Zainazor, T. C., Cheah, Y. K., \& Son, R. (2011). Biosafety assessment of Listeria monocytogenes in vegetarian burger patties in Malaysia. International Food Research Journal, 18, 459-463. 